J. Perinat. Med.

3 (1975) 166

\section{Blood in amniotic fluid following intrauterine transfusion and its effect on premature onset of labor}

\author{
P. Altmann, J. E. F. Bruce, F. Karnicki
}

Department of Obstetrics and Gynecology, Lewisham Hospital, London, S. E. 13

I. Universitäts-Frauenklinik, Vienna

Received June 8, 1974. Accepted February 24, 1975.
Premature onset of labor following intrauterine transfusion in severe rhesus hemolytic disease of the newborn remains a major cause of fetal loss inspite of improved methods of inhibiting uterine action (KARNICKI [6], QUEENAN [11], WALker et Ellis [13] and Whitefield et al. [15]). In the present study, it is demonstrated that in many cases this is related to contamination of the liquor by blood at the time of the procedure.

\section{Material}

For the last ten years intrauterine transfusion has been carried out at Lewisham Hospital in patients with severe rhesus hemolytic disease. Between November 1963 and the end of March 1973 a total of 1,779 rhesusimmunized patients were investigated and treated. Five hundred and seventeen patients, including three twin pregnancies, received between one and five intrauterine transfusions (mean 1.88).

Between the years 1966 and 1967, 65 of these patients were transfused using a self-retaining pigtail-catheter. This practice was discontinued because of excessive leakage of blood from the fetal abdomen into the amniotic fluid and fetal intestinal injury (KARNICKI [7]). Transfusion with this catheter was associated with premature onset of labor in 47 of the 65 cases (72.3 per cent). Because the effect on uterine. activity of longstanding presence of a self-retaining catheter is difficult to assess, these cases have been ex-

\section{Curriculum vitae}

Peter Altmann was born on July 5, 1942 in Vienna, Austria. At the age of 18 , be began his medical studies at the University of Vienna. He received bis $M$. $D$. degree there in December 1967. After having worked for nearly two years in several departments of the University of Vienna, be joined the faculty of the $I$. University Clinic for $\mathrm{Ob}$ stetrics and Gynecology in

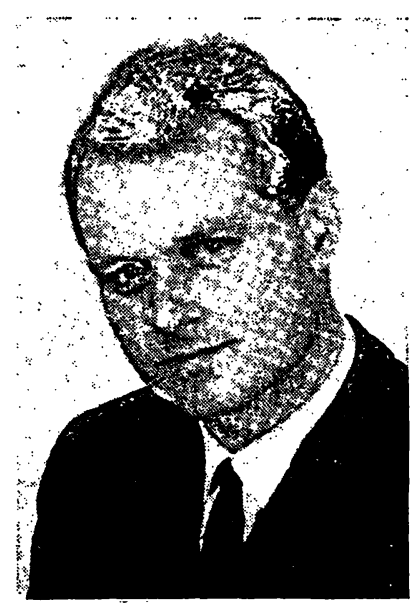

Vienna in November 1969. His special interest in perinatology led to a six-month scholarship by the Ministry of Science and Research, which enabled bim to study theoritical and practical problems involving the rbesus factor at Lewisham Hospital in London in 1973.

cluded from the present study. This left 452 cases for study of the effect of contamination of the liquor by blood on the onset of labor.

\section{Method}

Since 1965 it has been routine practice to localize the site of the placenta accurately in all patients with rhesus hemolytic disease before commencing investigation by amniocentesis, in order to minimize the risk of damage to the placenta. This was carried out in 420 of the 452 patients comprising the present study material. The indications for and the technique of intrauterine 
transfusion have previously been described (KARNICKI [6,7]).

A post-transfusion amniocentesis was performed in all cases, provided there was no evidence of uterine activity within 48 hours as determined by external tocography, in order to obtain liquor for bacteriological culture and to determine the presence of blood in the amniotic fluid as a result of the procedure. The presence of blood in the amniotic fluid was assessed either by posttransfusion amniocentesis or, when this was not carried out, from the notes made at the time the membranes ruptured in labor. Naturally care was taken to rule out the possibility that the cause of the presence of blood in the liquor was the second amniocentesis. Using a $4 \mathrm{~cm}$ long i. $\mathrm{m}$. needle without "mandrin", one can easily recognize an unfortunate puncture of placenta or uterine vessel.

\section{Results}

From the total group of 520 babies, 215 (41.3 per cent) survived. There were 171 (32.9 per cent) stillbirths and 134 (25.8 per cent) neonatal deaths. In 255 patients (49.3 per cent), including the three twin pregnancies, the onset of labor occured before the intended time. When the cases of neonatal death were considered separately, 71.8 per cent were associated with premature onset of labor. In the 452 cases where the transfusion catheter was removed immediately after each procedure, 208 (47.0 per cent) went into labor before the planned program of treatment could be completed. Of these 208 cases, 139 (66.8 per cent) went into labor in the first week, 57 (27.4 per cent) in the second week and 12 (5.6 per cent) in the third week after the last intrauterine transfusion (Tab. I).

The influence of blood contaminating the liquor on the onset of labor could only be assessed in 332 cases where the records were complete (Tab. II).

Taking this group as a whole, 61.6 per cent of those patients who went into labor within 21 days of the last intrauterine transfusion had contaminated liquor, whereas such was the case in only 34.8 per cent of those who did not go into labor within this period. Statistical analysis

Tab. I. Incidence and day of onset of labor before the intended time following intrauterine transfusion.

Onset of labor before the intended time after I. U. T. in days

\begin{tabular}{|c|c|c|c|c|c|c|c|c|c|c|c|c|c|c|c|c|}
\hline & 1 & 2 & 3 & 4 & 5 & 6 & 7 & 8 & 9 & 10 & 11 & 12 & 13 & 14 & $15-21$ & Total \\
\hline 456 & 23 & 28 & 22 & $\begin{array}{c}25 \\
139\end{array}$ & 13 & 10 & 18 & 12 & 12 & $\begin{array}{c}9 \\
57\end{array}$ & 6 & 4 & 5 & 9 & $\begin{array}{l}12 \\
12\end{array}$ & $\begin{array}{l}208 \\
208\end{array}$ \\
\hline $\begin{array}{l}\text { Percent of } \\
\text { Whole Group } \\
\text { Percent of } \\
\text { Patients Where } \\
\text { Labor }\end{array}$ & & & & $30.7 \%$ & & & & & & 12. & $6 \%$ & & & & $2.7 \%$ & $46.0 \%$ \\
\hline Occurred & & & & $66.8 \%$ & & & & & & 27. & $4 \%$ & & & & $5.6 \%$ & $100 \%$ \\
\hline
\end{tabular}

Tab. II. The effect of blood-contaminated liquor on the onset of labor before the intended time.

\begin{tabular}{|c|c|c|c|c|c|c|}
\hline & \multicolumn{2}{|c|}{ Stillbirth } & \multicolumn{2}{|c|}{ Livebirth } & \multicolumn{2}{|c|}{ Total } \\
\hline & \multicolumn{2}{|c|}{85} & \multicolumn{2}{|c|}{247} & \multicolumn{2}{|c|}{332} \\
\hline $\begin{array}{l}\text { Cases with Complete } \\
\text { Records }\end{array}$ & $\begin{array}{l}\text { Planned } \\
\text { Labor } \\
53\end{array}$ & $\begin{array}{l}\text { Unplanned } \\
\text { Labor } \\
32\end{array}$ & $\begin{array}{c}\text { Planned } \\
\text { Labor } \\
134\end{array}$ & $\begin{array}{l}\text { Unplanned } \\
\text { Labor } \\
113\end{array}$ & $\begin{array}{c}\text { Planned } \\
\text { Labor } \\
181\end{array}$ & $\begin{array}{c}\text { Unplanned } \\
\text { Labor } \\
151\end{array}$ \\
\hline $\begin{array}{l}\text { Liquor Contaminated } \\
\text { with Blood }\end{array}$ & $37 \begin{array}{c}(69.8 \%) \\
\text { Significa } \\
\mathrm{p}\end{array}$ & $\begin{array}{l}29(90.6 \%) \\
\text { Difference } \\
.05\end{array}$ & $\begin{array}{c}28(20.9 \%) \\
\text { High Signif } \\
\text { p }\end{array}$ & $\begin{array}{l}62(54.9 \%) \\
\text { th Difference } \\
001\end{array}$ & $\begin{array}{r}63(34.8 \%) \\
\text { High Signi } \\
\mathrm{p}<\end{array}$ & $\begin{array}{l}93(61.6 \%) \\
t \text { Difference } \\
001\end{array}$ \\
\hline
\end{tabular}


applying the chi-square test revealed this to be a highly significant difference $(p<0.001)$. As the presence of intrauterine death is known to stimulate the onset of labor, the effect of contaminated liquor was assessed separately for livebirths and stillbirths (Tab. II). In the livebirth group, when labor occured before the intended time, there was a 54.9 per cent incidence of contaminated liquor, compared with only a 20.9 per cent incidence when premature onset of labor did not occur. Again this was found to be a highly significant difference $(p<0.001)$. In the stillbirth group, 90.6 per cent of patients who went into labor before the intended time had contaminated liquor, as compared with 69.8 per cent of those who did not. Likewise, this was found to be a statistically significant difference $(p<0.05)$.

\section{Discussion}

Our results show that unplanned delivery before the intended time is a major problem following intrauterine transfusion. Inevitably this leads to an increase in the neonatal death rate, which can be expected to continue until more effective methods of inhibiting uterine action become available. Indeed, when the primary cause of each individual neonatal death was assessed for the whole series, it was found to be directly related to immaturity in 70 per cent of the cases. The tendency to go into labor following intrauterine transfusion was found to be greatest during the first four days; nearly 50 per cent of the cases occured during this time. In view of this, it would seem wise to confine patients to bed for this period, and to even consider the prophylactic use of drugs known to inhibit uterine action. A number of drugs such as Isoxuprine, Orciprenaline and Ritodrine are said to inhibit uterine activity. In recent years, the effectiveness of such beta-mimetic drugs in suppressing labor has been tested in several collaborative studies (DURAN-SANChes et al. [3], Fröhlich et al. [4], Wesselius de CASPARIs et al. [14]). Ethanol treatment has also become an accepted procedure for inhibiting labor in many clinics (Fuchs et al. [5], RYGEN [12]). Most of these authors report a sufficient inhibitory effect of the investigated drugs. This seems not to hold true for patients with bloodstained liquor. Furthermore, once labor has started, the use of the above-mentioned drugs has been rather disappointing in our experience. There are many factors which are known to influence the onset of labor. However, why labor should commence at a particular time still is only theory. One of the most attractive hypotheses, the result of some very elegant work on ewes by LIGGINS et al. $[9,10]$ proposes that the fetus determines its own time for delivery. LIGGINs [8] suggests further that the glucocorticoid effect of cortisol secreted by the female adrenals as a result of an increasing input of physiological stimuli to the hypothalamus could be the mediator. If this is so, it is hardly surprising that the stimuli which must be received by the fetal hypothalamus during an intrauterine transfusion lead to a high incidence of labor beginning before the intended time.

Little has been written about the effect of liquor contaminated with blood on uterine activity. BREHM et al. [1] described the treatment of severe rhesus hemolytic disease by prenatal injection of blood into the amniotic cavity. They found that 10 to 15 per cent of the cells introduced into the liquor were later detectable in the neonatal circulation, but comment that the one disadvantage of the procedure was premature onset of labor. This occured 8 to 17 days after the first intra-amniotic transfusion. In these cases, up to 500 millilitres of blood at a time were introduced into the amniotic cavity, so it is perhaps hardly surprising that labor ensued.

Our results show that the presence of blood, presumably leaking from the fetal abdomen, has a significant effect on uterine activity. Therefore, if liquor is found to be contaminated by blood when posttransfusion amniocentesis is performed, we recommend that these patients be kept in the hospital and prophylactic measures to inhibit uterine activity be considered.

We know of no way of preventing the leakage of blood from the fetal abdomen contaminating the liquor in cases where it does occur. However, damage to the placenta either during intrauterine transfusion or amniocentesis which results in contamination can be prevented by accurate 
prior localisation. Not only is this of importance in relation to the onset of unplanned labor, but equally because blood in the liquor makes accurate assessment of optical density impossible.

\section{Summary}

The most frequent cause of perinatal death following intrauterine transfusion in cases of severe rhesus hemolytic disease remains premature onset of labor and the resulting newborn so delivered. In the present study, $70 \%$ of all perinatal deaths were directly related to immaturity. A factor of decisive importance as an initiator of labor before the intended time is the leakage of blood into the amniotic fluid at the time of the procedure. (Mostly, this blood seems to originate from the fetal abdomen into which it was injected for therapeutic reasons.)

The effect of blood-contaminated amniotic fluid on uterine activity is demonstrated on the material from Lewisham Hospital of London, where between 1 and 5 intrauterine transfusions were performed on 517 patients during a period between November 1963 and the end of March 1973. The presence of blood in the amniotic fluid was proved either by means of amniocentesis performed 2 days after intrauterine transfusion, or at the time of membrane rupture in labor. Patients who received a self-retaining catheter for any length of time were excluded from the material since the additive influence of the catheter on labor could not be assessed. Out of a total of 452 cases receiving single-use catheters, there were 208 cases (46\%) with premature onset of labor. In two-thirds of the cases this happened within the first week after the last intrauterine transfusion (Tab. I).

Further investigation of 332 case-histories with complete records was carried out. In $61.6 \%$ of the patients with labor before the intended time writhin 21 days after the last intrauterine transfusion, blood contaminated amniotic fluid was found, whereas this occurred in only $34.8 \%$ of the cases without premature onset of labor ( $p<0.001)$. From the same material, corresponding percentages for livebirths and stillbirths were calculated (Tab. II).

As a consequence of these results, it is recommended that patients be kept under intensive hospital care following intrauterine transfusion whenever blood can be proved to be present in the amniotic fluid. Prophylactic measures to prevent premature onset of labor should also be considered.

Keywords: Amniotic fluid, intrauterine transfusion, labor, perinatal mortality, rhesus hemolytic disease.

\section{Zusammenfassung}

Der Einfluß von Blut im Fruchtwasser nach intrauteriner Transfusion auf den vorzeitigen Wehenbeginn.

Die häufigste Ursache perinataler Mortalität nach durchgeführter intrauteriner Transfusion beim schweren Morbus haemolyticus fetalis ist trotz Anwendung von Wehenhemmern die Unreife des Neugeborenen. Im vorliegenden Material waren $70 \%$ aller perinatal verstorbener Kinder unreif. Eine entscheidende Bedeutung bei der Auslösung vorzeitiger Wehen erlangt das in die Amnionhöhle gelangte Blut. (Es handelt sich zumeist um rückströmendes Blut aus dem fetalen Peritonealraum, wohin es aus therapeutischen Gründen injiziert worden war).

Anhand des Materials des Lewisham Hospitals, London, wo von November 1963 bis 31. 3. 1973 an 517 Patientinnen zwischen 1 und 5 intrauterine Transfusionen durchgeführt worden waren, konnte dieser Effekt nachgewiesen werden. Die Anwesenheit von Blut im Fruchtwasser, wurde entweder durch eine 2 Tage nach der intrauterinen Transfusion durchgeführten Amnionzentese oder, gegebenenfalls, beim vorzeitigen Blasensprung festgestellt. Patientinnen, bei welchen Verweilkatheter über einige Tage zur Anwendung kamen, wurden aufgrund des nicht abzu- schätzenden zusätzlichen Einflusses des Katheters auf die Wehentätigkeit von der Untersuchung ausgeschlossen. Von 452 Fällen kam es, nach Verwendung von E.inmalkathetern, in 208 Fällen (46,0\%) zum vorzeitigen Wehenbeginn, wobei dieses Ereignis in 2 Drittel der Fälle innerhalb der ersten Woche auftrat (Tab. I). Zur weiteren Untersuchung wurden 332 Krankenblätter mit vollständigen Aufzeichnungen herangezogen. Bei 61,6\% der Patientinnen mit vorzeitigem Wehenbeginn innerhalb von 21 Tagen nach der letzten intrauterinen Transfusion bestand blutig-tingiertes Fruchtwasser, während ein solches nur in $34,8 \%$ der Fälle ohne vorzeitigem Wehenbeginn gefunden wurde $(p<0,001)$. Bei weiterer Aufschlüsselung des Materials konnten für Lebendgeborene und Totgeburten entsprechende Prozentsätze errechnet werden (Tab. II). Aufgrund dieser Ergebnisse erhebt sich die Forderung, die Patientin sofort in stationäre Behandlung zu nehmen, wenn Blut im Fruchtwasser nachgewiesen wurde. Intensivste prophylaktische $\mathrm{Maß}$ nahmen zur Unterdrückung jeder Wehentätigkeit sollten unternommen werden.

Schlüsselworte: Fruchtwasser, intrauterine Transfusion, perinatale Mortalität, Rhesus-Unverträglichkeit, Wehen (vorzeitige). 


\section{Résumé}

Influence du sang dans le liquide amniotique après transfusion intrautérine sur le déclenchement prématuré du travail

La cause la plus fréquente de la mortalité périnatale après transfusion intrautérine effectuée en cas de morbus haemolyticus fetalis grave est l'immaturité du nouveau-né malgré les tentatives d'inhibition du travail. Dans le matériel présent, $70 \%$ des enfants morts en périnatalité étaient immatures. Un facteur déterminant du déclenchement prématuré du travail est la présence de sang dans la cavité amniotique. (Il s'agit le plus souvent d'un reflux sanguin de l'espace péritonéal foetal où le sang avait été injecté pour des raisons thérapeutiques).

On a pu vérifier cet effet à l'aide du matériel du Lewisham Hospital de Londres où on avait pratiqué de 1 à 5 transfusions intrautérines à 517 patientes entre nov. 1963 et le 31. 3. 1973. La présence de sang dans le liquide amniotique avait été constatée après amniocentèse effectuée deux jours après la transfusion intrautérine ou, le cas échéant, après la rupture prématurée des membranes. On a exclu de l'étude présente les patientes qui avaient reçu pendant plusieurs jours une sonde à demeure dọnt il est difficile d'évaluer l'influence supplémentaire sur le travail. Par contre, sur les 452 cas avec application de sondes une seule fois, 208 $(46,0 \%)$ ont enregistré un déclenchement prématuré du travail qui se produisit dans les deux tiers des cas moins d'une semaine après (Tab. I). Pour compléter l'étude, on s'est reporté à 332 dossiers médicaux complets. On a constaté que chez $61,6 \%$ des patientes avec déclenchement prématuré du travail moins de 21 jours après la dernière transfusion intrautérine, le liquide amniotique était teinté de sang tandis que cela ne s'était produit que dans 34,8\% des cas sans déclenchement prématuré du travail ( $p$ $<0,001)$. Une étude plus approfondie du matériel a permis de calculer des pourcentages correspondants pour les nouveaux-nés vivants et les morts-nés (Tab. II). Ces résultats indiquent la nécessité d'hospitaliser immédiatement les patientes chez lesquelles on a pu détecter la présence de sang dans le liquide amniotique et de prendre les mesures prophylactiques les plus intensives pour réprimer toute manifestation de travail.

Mots-clés: Hémolyse Rh, liquide amniotique, mortalité périnatale, travail, transfusion intraụtérine.

\section{Acknowledgements}

We are grateful to Dr. C. A. Holman, Consultant Hematologist at Lewisham Hospital, for advice, and to Miss Hinrary Pontrs at King's College Hospital for the statistical analysis.

\section{Bibliography}

[1] BREHM, H.: Intra-amniotic transfusion and the treatment of anaemia in the newborn. In: HuntingFORD, P. J., K.-A. Hüter, E. SAling: Perinatal Medicine, 1st European Congress, Berlin. Thieme, Stuttgart 1969

[2] BREHM, H., S. SeIdL, B. MAY: Die intraamniale Bluttransfusion zur symptomatischen Behandlung der fetalen Erythroblastose. Med. Welt 18 (1967) 61

[3] Duran Sanchez, P., A. Rene, M. Carreras, L. Cabero, M. Sostoa, O. Gamissans, J. EstebanAltirriba: Orciprenaline and Ritodrine. A comparative study. Proceedings of the international symposium on the treatment of fetal risks. Baden/ Austria, 1972

[4] Fröhlich, H., K. Baumgarten, W. Gruber, N. Klearchou, A. Seidi, G. Urban: Vergleichende Untersuchungen von Ritodrine und Th $1165 \mathrm{a}$ zur Behandlung der drohenden Frühgeburt. Proceedings of the international symposium on the treatment of fetal risks. Baden/Austria 1972

[5] Fuchs, F., A. R. Fuchs, V. F. Poblete Jr., A. Risk: Effect of alcohol on threatened premature labor. Amer. J. Obstet, Gynec. 99 (1967) 627

[6] KARNICKY, J.: Results and hazards of prenatal transfusion. J. Obstet. Gynaec. Brit. Cwlth. 75 (1968) 1209
[7] Karnicky, J.: Present status of thesusisoimmunisation. Proceedings of the International Symposion on obstetrics and gynaecology. Carlo Erba Foundation, Milan 1969

[8] LIGgINs, G. C.: The fetal role in the initiation of parturition in the ewe. In: Fetal Autonomy. Ciba Foundation Symposium J. A. Churchill, London 1968

[9] Liggins, G. C., P. G. KenNedy: Effects of elèctrocoagulation of the fetal lamb hypophysis on growth and development. J. Endocrinology 40 (1968) 371

[10] Lrgans, G. C., P. C. Kennedy, L. W. Holm: Failure of initiation of parturirion after electrocoagulation of the pitiutary of the fetal lamb. Amer. J. Obstet. Gynec. 98 (1967) 1080

[11] QueEnaN, J. T.: Intrauterine transfusion. A cooperative study. Amer. J. Obstet. Gynec. 104 (1969) 397

[12] RYDEN, G.: Treatment of premature labour with ethanol and the elimination of ethanol in the premature infant. Proceedings of the international symposium on the treatment of fetal risks. Baden/Austria

[13] WaLkER, W., M. I. Ellis: Intrauterine transfusion. Brit. Med. J. 2 (1970) 223 
[14] Wesselius de Casparis, A., M. Thiert, A. Yo le Sinn, K. Bacmgarten, I. Brosens, O. Ganissans, J. G. StOLK, IF. VIVIER: Results of a double-blind, multicentre study with Ritodrine in premature labour. Brit. med. J. 3 (1971) 144
[15] Whitepield, C. R., W'. ThonpsoN, M. J. Arnstrong, M. MCReID: Intrauterine fetal transfusion for severe rhesus hemolytic disease. J. Obstet. Gynee. Brit. Cwith. 79 (1972) 931

Dr. P. Altmann

I. Universitäts-Fraucnklinik Spitalgasse 23

1090 Wien $1 \mathrm{~A}$; Austria 